\title{
PLA2G2A Gene
}

National Cancer Institute

\section{Source}

National Cancer Institute. PLA2G2A Gene. NCI Thesaurus. Code C24678.

This gene is involved in the regulation of the inflammatory response. 